\title{
Antioxidant and antibacterial activity and preliminary toxicity analysis of four varieties of avocado (Persea americana Mill.)
}

\author{
Atividades antioxidante e antibacteriana e análise preliminar \\ da toxicidade de diferentes variedades de abacate \\ (Persea americana Mill.)
}

Daieni Alves Vieira Amado ${ }^{* *}$ (1), Giovani Andrey Bet Helmann', Alessandra Maria Detoni², Sérgio Luiz Colucci de Carvalho ${ }^{3}$, Caroline Mariana de Aguiar ${ }^{1}$, Clayton Antunes Martin ${ }^{1}$, Tatiana Shioji Tiuman', Solange Maria Cottica ${ }^{1}$ (i)

${ }^{1}$ Universidade Tecnológica Federal do Paraná (UTFPR), Departamento de Processos Químicos, Toledo/PR - Brasil ${ }^{2}$ Instituto Agronômico do Paraná (IAPAR), Estação Experimental de Santa Tereza do Oeste, Santa Tereza do Oeste/PR - Brasil

${ }^{3}$ Instituto Agronômico do Paraná (IAPAR), Estação Experimental de Londrina, Londrina/PR - Brasil

*Corresponding Author: Daieni Alves Vieira Amado, Universidade Tecnológica Federal do Paraná (UTFPR), Rua Cristo Rei, 19, CEP: 85902-490, Toledo/PR - Brasil, e-mail: daienivieira@gmail.com

Cite as: Amado, D. A. V., Helmann, G. A. B., Detoni, A. M., Carvalho, S. L. C., Aguiar, C. M., Martin, C. A., Tiuman, T. S., \& Cottica, S. M. (2019). Antioxidant and antibacterial activity and preliminary toxicity analysis of four varieties of avocado (Persea americana Mill.). Brazilian Journal of Food Technology, 22, e2018044. https://doi.org/10.1590/1981-6723.04418

\begin{abstract}
The antioxidant and antibacterial activity and toxicity of natural products can change according to plant variety, as well as the part of the plant which is analyzed. In this study, peel, pulp and seed of four avocado varieties (Quintal, Fortuna, Margarida, and Hass) were analyzed for antioxidant and antibacterial properties and toxicity. There are few studies in the literature comparing these three first varieties. Antioxidant capacity was measured using the DPPH (2,2-diphenyl-1-picrylhydrazil), ABTS [2,2'-azino-bis- (3-ethylbenzothiazoline-6-sulfonic acid)], and FRAP (Ferric Reducing Ability Power) methods, along with the content of phenolic compounds and flavonoids. Principal component analysis was applied for antioxidant tests. Antibacterial activity against food pathogens was assessed by the minimum inhibitory concentration and minimum bactericidal concentration tests. Toxicity was evaluated against Artemia salina and also by hemolytic activity. The ethanolic extract of Quintal variety peel presented the greatest antioxidant and antibacterial activity. This same extract showed no toxicity in the preliminary tests, and shows great potential for food industry application as an additive.
\end{abstract}

Keywords: Phenolic compounds; Flavonoid; Artemia salina; Hemolytic activity; Fruit; Byproduct.

\section{Resumo}

As atividades antioxidante e antibacteriana, e a toxicidade de produtos naturais podem mudar de acordo com a variedade vegetal, bem como a parte da planta que é analisada. Neste estudo, foram analisadas cascas, polpas e sementes de quatro variedades de abacate (Quintal, Fortuna, Margarida e Hass) no que tange às propriedades 
antioxidantes e antibacterianas, e à toxicidade. Existem poucos estudos na literatura comparando essas três primeiras variedades. A atividade antioxidante foi medida utilizando-se os métodos DPPH (2,2-diphenyl-1picrylhydrazil), ABTS [2,2'-azino-bis- (3-ethylbenzothiazoline-6-sulfonic acid)] e FRAP (Ferric Reducing Ability Power), juntamente com o conteúdo de compostos fenólicos e flavonoides. A análise de componentes principais foi aplicada para testes antioxidantes. A atividade antibacteriana contra patógenos alimentares foi avaliada pelos testes de concentração inibitória mínima e concentração bactericida mínima. A toxicidade foi avaliada contra Artemia salina e também pela atividade hemolítica. O extrato etanólico da casca da variedade Quintal apresentou a maior atividade antioxidante e antibacteriana. Este mesmo extrato não mostrou toxicidade nos testes preliminares e mostra grande potencial de aplicação na indústria de alimentos como um aditivo alimentar.

Palavras-chave: Compostos fenólicos; Flavonoide; Artemia salina; Atividade hemolítica; Fruta; Subproduto.

\section{Introduction}

There is currently great popular interest in natural products, which has motivated the search for a new source of bioactive compounds that can be beneficial for human consumption in place of synthetic compounds used in food industry as additives, and can contribute to the reduction of generated waste, giving them a much more beneficial destination (Rodríguez-Carpena et al., 2011). Bioactive compounds related to antioxidant capacity have been the subject of research because of their high importance in human health (Paz et al., 2015).

The avocado (Persea americana Mill) is a fruit with antioxidant and antibacterial properties, produced in almost all tropical and subtropical regions of the world (Kate \& Lucky, 2009). There are some studies on the total phenolic content and antioxidant and antibacterial capacity of different avocado varieties. However, there are no study in the literature comparing these properties of the varieties Quintal, Fortuna and Margarida. Additionally, industrial processing of avocados generates a large amount of peels and seeds as waste. Investigating the phytochemical content of this waste can lead to new products for food, cosmetic and pharmaceutical industry that can add value to avocado production.

The avocado world production is increasing, with Mexico, Dominican Republic, Peru, Colombia, Indonesia, Brazil, Kenya, United States, Chile and China occupying the top ten positions regarding world production in the harvest of 2016 (Food and Agricultural Organization, 2017). Brazil is one of the main avocado producing countries in the world context, having in the last decades an average production of approximately 154.5 thousand tons (Informa Economics IEG, 2017).

Consequently, the objective of this study was to analyze extracts of the pulp, peel, and seed of four avocado varieties (Quintal, Hass, Fortuna, and Margarida) in terms of their antioxidant and antibacterial activities and preliminary toxicity testing.

\section{Material and methods}

\subsection{Sampling}

Four varieties of avocados (Quintal, Hass, Margarida, and Fortuna) grown and harvested by the Agronomic Institute of Paraná (IAPAR) in Santa Helena and Londrina, Paraná, Brazil from the 2015 harvest were used. Twenty fruits of each variety were used in the study, being carefully collected and kept in room temperature until ripe. Next, for batch homogenization, they were selected as to size, color and absence of injuries and defects, washed with distilled water, manually separated into pulp, peel and seed, and were size-reduced and homogenized in food microprocessor. The different parts of each variety were subsequently vacuum packed into polyethylene bags, stored at $-18{ }^{\circ} \mathrm{C}$, and protected from light until analysis. 


\subsection{Extracts preparation}

In order to assess the antioxidant and antimicrobial activities, the phenolic compounds, and total flavonoids, ethanolic extracts of the fruits (peel, pulp, and seed) were obtained by adding ethanol solvent $1: 10(\mathrm{~m} / \mathrm{v})$ and stirring for 4 hours while protected from light (Ribeiro et al., 2013). After vacuum filtration, the solvent was evaporated using a rotary evaporator at $37{ }^{\circ} \mathrm{C}$ under reduced pressure. The dried extracts were stored in light-protected vessels at $-18^{\circ} \mathrm{C}$ until the time of analysis.

\subsection{Antioxidant capacity}

\subsubsection{Ability to capture the radical DPPH (2,2-diphenyl-1-picrylhydrazil)}

The ability to capture free radicals was determined in triplicate using DPPH as described in the literature (Bondet et al., 1997), with some modifications according to Boroski et al. (2015). Initially, several volumes (range: 50 to $250 \mu \mathrm{L}$ ) of ethanolic solutions of the avocado extracts (peel, pulp, and seed) $\left(2 \mathrm{mg} \mathrm{mL}^{-1}\right)$ were added to $2 \mathrm{~mL}$ of ethanolic DPPH solution $\left(0.06 \mathrm{mmol} \mathrm{L}^{-1}\right)$ and kept in the dark for 30 minutes at room temperature. The absorbance was measured in a UV-VIS spectrophotometer at $517 \mathrm{~nm}$, using ethanol as a blank. Results were expressed in $\mu \mathrm{M}$ Trolox equivalent (TE) $\mathrm{g}^{-1}$ of dried avocado sample, using $50 \mu \mathrm{L}$ of ethanolic solutions of the avocado extracts (peel, pulp, and seed) $\left(2 \mathrm{mg} \mathrm{mL}^{-1}\right)$ and Trolox standard calibration curve $\left(0\right.$ to $\left.2000 \mu \mathrm{mol} \mathrm{L}^{-1}\right)$. Results were also expressed as antioxidant capacity index (AAI) (Scherer \& Godoy, 2009) that evaluates antioxidant efficiency in plant extracts.

\subsubsection{Capture of the free radical ABTS [2,2'-azino-bis- (3-ethylbenzothiazoline-6-sulfonic acid)]}

Antioxidant capacity according to the ABTS method was determined in triplicate according to Re et al. (1999), with some modifications according to Boroski et al. (2015). Extracts concentration were $2 \mathrm{mg} \mathrm{mL}^{-1}$, and Trolox ( 0 to $2000 \mu \mathrm{mol} \mathrm{L}^{-1}$ ) was used to construct the standard curve. The absorbance was measured in a UV-VIS spectrophotometer at $734 \mathrm{~nm}$, using ethanol as a blank. Antioxidant capacity results were expressed in $\mu \mathrm{M}$ Trolox equivalent (TE) $\mathrm{g}^{-1}$ of the dried avocado sample.

\subsubsection{Fe(III) reducing power using the FRAP method}

Analysis of reducing power using FRAP (Ferric Reducing Ability Power) was performed in triplicate according to Benzie \& Strain (1996), with some modifications according to Boroski et al. (2015). Extracts concentration used were $2 \mathrm{mg} \mathrm{mL}^{-1}$ and the absorbance was read in a UV-VIS spectrophotometer at $593 \mathrm{~nm}$, using water as a blank. The antioxidant potential of the avocado extracts to reduce $\mathrm{Fe}$ (III) to $\mathrm{Fe}(\mathrm{II})$ was expressed as $\mu \mathrm{mol} \mathrm{Fe}(\mathrm{II}) \mathrm{g}^{-1}$ of the dried avocado sample using the calibration curve obtained with $\mathrm{FeSO}_{4} .7 \mathrm{H}_{2} \mathrm{O}\left(0\right.$ to $\left.2000 \mu \mathrm{mol} \mathrm{L}^{-1}\right)$.

\subsection{Total Phenolic Compounds (TPC)}

The total content of phenolic compounds was determined in triplicate according to Singleton \& Rossi (1965), with some modifications according to Boroski et al. (2015), using Folin-Ciocalteau reagent. Ethanolic solutions of avocado extracts (peel, pulp, and seed) at concentrations of $2.5 \mathrm{mg} \mathrm{mL}^{-1}$ were prepared, and the absorbance was measured at $725 \mathrm{~nm}$ in a UV-VIS spectrophotometer, using ethanol as a blank. The total content of phenolic compounds was determined using the calibration curve for gallic acid, and was expressed as $\mathrm{mg}$ gallic acid equivalent (EAG) $\mathrm{g}^{-1}$ of the dried avocado sample. 


\subsection{Flavonoid content (FLA)}

Flavonoid content was determined in triplicate using the method described by Woisky \& Salatino (1998), with some modifications according to Boroski et al. (2015). Ethanolic solutions of avocado extracts (peel, pulp, and seed) $\left(2.5 \mathrm{mg} \mathrm{mL}^{-1}\right)$ were prepared and the absorbance was measured at $425 \mathrm{~nm}$ in the UV-VIS spectrophotometer at room temperature, using ethanol as a blank. The total content of flavonoids was determined using the calibration curve for quercetin and was expressed as mg quercetin equivalent (EQ) $\mathrm{g}^{-1}$ of the dried avocado sample.

\subsection{Antibacterial activity}

\subsubsection{Microorganisms and culture}

The antibacterial properties were tested against gram-positive strains of the bacteria Staphylococcus aureus (ATCC 14458) and Bacillus cereus (ATCC 11778) and gram-negative strains of Salmonella typhi (ATCC 06539) and Escherichia coli (ATCC 10536).

\subsubsection{Determination of Minimum Inhibitory Concentration (MIC)}

The antibacterial activity of the extracts was determined in triplicate using the broth microdilution method proposed by the Clinical and Laboratory Standards Institute in document M07-A9 (Clinical and Laboratory Standards Institute, 2012). The concentration of the crude extract solutions added were 40 to $0.312 \mathrm{mg} \mathrm{mL}^{-1}$, and $10 \mu \mathrm{L}$ of each bacterial culture, at a density of $10^{6} \mathrm{CFU} \mathrm{mL}^{-1}$, were placed in each well. Control of microbial growth was also performed, and the positive control used the standard antibiotic ampicillin. Microbial growth in the wells was confirmed by applying $20 \mu \mathrm{L}$ of a sterile aqueous solution of triphenyltetrazolium chloride (TTC) $0.5 \%$ to all wells on each plate. The MIC was defined as the lowest concentration of the extract in $\mathrm{mg} \cdot \mathrm{mL}^{-1}$ which was able to prevent microbial growth.

\subsubsection{Determination of Minimum Bactericidal Concentration (MBC)}

To determine MBC, a subculture using Mueller-Hinton agar (MHA) was done using the contents of the wells in the MIC test in which no bacterial growth was seen, prior to the addition of TTC. The plates were then incubated in an oven at $37^{\circ} \mathrm{C}$ for 24 hours. The MBC is defined as the lowest concentration that causes death in $99.9 \%$ or more of the bacterial inoculum used. Tests were performed in triplicate.

\subsection{Toxicity testing}

\subsubsection{Toxicity against Artemia salina (A. salina)}

Toxicity of the extract against the brine shrimp (A. salina) was assessed according to Meyer et al. (1982), with some modifications. The tested concentrations were $300 \mathrm{mg} \mathrm{mL}^{-1} ; 250 \mathrm{mg} \mathrm{mL}^{-1} ; 200 \mathrm{mg} \mathrm{mL}^{-1} ; 150 \mathrm{mg}$ $\mathrm{mL}^{-1} ; 100 \mathrm{mg} \mathrm{mL}^{-1} ; 50 \mathrm{mg} \mathrm{mL}^{-1}$, and $25 \mathrm{mg} \mathrm{mL}^{-1}$ using dimethylsulfoxide (DMSO) $0.5 \%$ and saline solution to aid in extract solubilization. The negative controls were prepared using Meyer solution with DMSO 0.5\%, and positive controls were prepared with a $1.0 \%$ potassium dichromate solution. The lethal concentration that causes the death of $50 \%$ of organisms $\left(\mathrm{LC}_{50}\right)$ was obtained by linear regression using Probits analysis in Microsoft Excel 2013.

\subsubsection{Toxicity via hemolytic activity}

The toxicity test was assessed according to Tiuman et al. (2005) and the crude extracts, diluted at the same concentrations as those used in the A. salina test using DMSO $0.5 \%$ to solubilize the extract. Samples were 
read using a spectrophotometer at $540 \mathrm{~nm}$, using a $5 \%$ glucose solution as the blank. In this test, we used the $4 \%$ erythrocyte suspension with DMSO $0.5 \%$ as the negative control and a $1 \%$ solution of Triton X 114 as a positive control. A blank was also prepared for each concentration.

\subsection{Statistical analysis}

Results were subjected to analysis of variance (ANOVA) and the Tukey test (5\% probability), using the Agricolae package for $\mathrm{R}$ software. The mean values were compared using the Tukey test. Principal component analysis (PCA) was performed using Statistica software, version 7.0.

\section{Results and discussion}

\subsection{Analysis of antioxidant capacity}

The phenolic compounds present in plants are the main components responsible for antioxidant capacity (Ignat et al., 2011). The total content of phenolic compounds in this experiment varied from 1.30 to $38.82 \mathrm{mg} \mathrm{EAG} \mathrm{g}^{-1}$ of dry sample (Table 1). The peel extract from the Quintal variety exhibited the highest level of phenolic compounds, with $38.82 \mathrm{mg} \mathrm{EAG} \mathrm{g}^{-1}$ dry sample.

Table 1. Total phenolic compounds and flavonoids for the Quintal, Fortuna, Margarida, and Hass varieties of avocado.

\begin{tabular}{cccccccc}
\hline & \multicolumn{2}{c}{ Total phenolic compounds $\left.(\mathbf{m g ~ E A G ~ g})^{-1}\right)$} & & \multicolumn{3}{c}{ Flavonoid content $\left(\mathbf{m g ~ E Q ~}^{-1}\right)$} \\
\cline { 1 - 3 } & Peel & Pulp & Seed & & Peel & Pulp & Seed \\
\hline Hass & $16.15 \pm 0.04^{\mathrm{Ab}}$ & $2.04 \pm 0.04^{\mathrm{Ca}}$ & $8.07 \pm 0.03^{\mathrm{Bb}}$ & & $0.84 \pm 0.04^{\mathrm{Ab}}$ & $0.31 \pm 0.02^{\mathrm{Bb}}$ & $0.26 \pm 0.02^{\mathrm{Bc}}$ \\
Quintal & $38.82 \pm 0.03^{\mathrm{Aa}}$ & $1.82 \pm 0.08^{\mathrm{Ca}}$ & $11.36 \pm 0.11^{\mathrm{Ba}}$ & & $2.74 \pm 0.18^{\mathrm{Aa}}$ & $0.43 \pm 0.02^{\mathrm{Ba}}$ & $0.65 \pm 0.04^{\mathrm{Ba}}$ \\
Fortuna & $10.71 \pm 0.15^{\mathrm{Ac}}$ & $1.30 \pm 0.16^{\mathrm{Cb}}$ & $8.24 \pm 0.18^{\mathrm{Bb}}$ & & $0.85 \pm 0.02^{\mathrm{Ab}}$ & $0.19 \pm 0.01^{\mathrm{Cc}}$ & $0.39 \pm 0.01^{\mathrm{Bb}}$ \\
Margarida & $5.45 \pm 0.38^{\mathrm{Ad}}$ & $1.91 \pm 0.01^{\mathrm{Ba}}$ & $2.05 \pm 0.02^{\mathrm{Bc}}$ & & $0.86 \pm 0.02^{\mathrm{Ab}}$ & $0.30 \pm 0.01^{\mathrm{Bb}}$ & $0.19 \pm 0.01^{\mathrm{Cc}}$ \\
\hline
\end{tabular}

Mean of 3 replicates \pm standard deviation on dry basis. Different capital letters on the same line, for each analysis, correspond to significant difference between different parts for the same variety $(p<0.05)$ by Tukey's test. Different small letters in the same column correspond to significant difference of the same part for the different varieties $(p<0.05)$ by Tukey's test.

In a study by Wang et al. (2010), who assessed antioxidant capacity and phenolic compounds of eight varieties of avocado, the Hass variety presented phenolic compound levels of 12.6, 4.9, and $51.5 \mathrm{mg} \mathrm{EAG} \mathrm{g}^{-1}$ of dry sample for peel, pulp, and seed, respectively. These results were lower than those of present study for the peel and higher for the pulp and seed. This difference is probably due to the different solvents and conditions used in the extraction. According to Soares et al. (1998), a number of factors are important during the extractive process such as the solvent penetration in the cells, dissolution of extractable substances and solution diffusion outside the plant cell, temperature, $\mathrm{pH}$, the nature of the solvent, extraction time, and the presence of pro-oxidant agents such as metals or light.

Some studies have demonstrated high levels of phenolic compounds in the peels and seeds of avocado, as can be seen in this present study. Matsusaka \& Kawabata (2010) found 75 and $35 \mathrm{mg} \mathrm{EAG} \mathrm{g}{ }^{-1}$ dry sample in $50 \%$ hydro-alcoholic extracts (v/v) for avocado peel and seed, respectively. And Daiuto et al. (2014) obtained 63.5 and $57.3 \mathrm{mg} \mathrm{EAG} \mathrm{g}^{-1}$ dry specimen for the peel and seed extracts, respectively, of Hass variety avocados extracted using ethanol:water $(80: 20 \mathrm{v} / \mathrm{v})$.

The phenolic compounds content can vary in the different parts of the fruit; greater concentrations of these compounds are generally seen in the peels. It is probable that phenolic compounds tend to accumulate in the epidermis of the fruits as a form of protection from ultraviolet radiation and defense against certain pathogens and predators (Dixon \& Paiva, 1995). 
In terms of flavonoid content, the peel extract of the Quintal variety stood out with $2.74 \mathrm{mg} \mathrm{EQ} \mathrm{g}^{-1}$ dry sample, showing the best results, significantly higher $(p<0.05)$ than the other parts of this same variety and also significantly higher when the peel of this variety was compared with the others. Since the pulp generally showed lower values of phenolic compounds and flavonoids than the peel and seed, these compounds are mostly present in the byproducts of the fruit which are typically discarded when fruit is consumed in its natural state or during processing. This suggests a great potential for the use of these byproducts as a source of food additives, at pharmaceutical industry and dermocosmetic.

According to Scherer \& Godoy (2009), plant extracts with AAI values below 0.5 are considered weak antioxidants, between 0.5 and 1.0 are considered moderate, between 1.0 and 2.0 are considered strong, and above 2.0 are considered very strong antioxidants. In present study, peel and seed of Quintal variety are considered strong antioxidants, peel and seed of Hass variety are considered moderate, and the other extracts are considered weak antioxidants by the DPPH method (Table 2).

Table 2. Antioxidant capacity assessed by different methods in different parts of the four avocado varieties.

\begin{tabular}{|c|c|c|c|c|c|c|}
\hline & \multicolumn{3}{|c|}{ DPPH $\left(\mu \mathrm{mol}\right.$ TE $\left.\mathrm{g}^{-1}\right)$} & \multicolumn{3}{|c|}{ AAI } \\
\hline & Peel & Pulp & Seed & Peel & Pulp & Seed \\
\hline Hass & $250.01 \pm 0.71^{\mathrm{Ab}}$ & $21.28 \pm 0.91^{\mathrm{Cd}}$ & $122.15 \pm 0.76^{\mathrm{Bb}}$ & $0.62 \pm 0.01^{\mathrm{Bb}}$ & $0.16 \pm 0.01^{\mathrm{Cb}}$ & $0.71 \pm 0.01^{\mathrm{Ab}}$ \\
\hline Quintal & $482.65 \pm 0.19^{\mathrm{Aa}}$ & $27.37 \pm 0.56^{\mathrm{Cb}}$ & $379.63 \pm 0.54^{\mathrm{Ba}}$ & $1.61 \pm 0.05^{\mathrm{Aa}}$ & $0.18 \pm 0.01^{\mathrm{Ca}}$ & $1.01 \pm 0.01^{\mathrm{Ba}}$ \\
\hline Fortuna & $156.78 \pm 2.07^{\mathrm{Ac}}$ & $23.87 \pm 0.18^{\mathrm{Cc}}$ & $121.83 \pm 0.12^{\mathrm{Bb}}$ & $0.32 \pm 0.01^{\mathrm{Bc}}$ & $0.06 \pm 0.02^{\mathrm{Cd}}$ & $0.45 \pm 0.01^{\mathrm{Ac}}$ \\
\hline \multirow[t]{3}{*}{ Margarida } & $156.47 \pm 0.60^{\mathrm{Ac}}$ & $38.94 \pm 0.58^{\mathrm{Ca}}$ & $42.75 \pm 0.12^{\mathrm{Bc}}$ & $0.32 \pm 0.01^{\mathrm{Ac}}$ & $0.09 \pm 0.01^{\mathrm{Cc}}$ & $0.20 \pm 0.01^{\mathrm{Bd}}$ \\
\hline & \multicolumn{3}{|c|}{ ABTS $\left(\mu \mathrm{mol} \mathrm{TE} \mathrm{g}^{-1}\right)$} & \multicolumn{3}{|c|}{ FRAP $\left(\mu \mathrm{mol}\right.$ de Fe II g $\left.{ }^{-1}\right)$} \\
\hline & Peel & Pulp & Seed & Peel & Pulp & Seed \\
\hline Hass & $313.46 \pm 0.72^{\mathrm{Ab}}$ & $2.34 \pm 0.21^{\mathrm{Cd}}$ & $17.28 \pm 0.12^{\mathrm{Bc}}$ & $337.58 \pm 0.33^{\mathrm{Ab}}$ & $3.62 \pm 0.15^{\mathrm{Cc}}$ & $25.43 \pm 0.38^{\mathrm{Bc}}$ \\
\hline Quintal & $497.53 \pm 0.01^{\mathrm{Aa}}$ & $7.53 \pm 0.26^{\mathrm{Cb}}$ & $122.90 \pm 0.23^{\mathrm{Ba}}$ & $546.49 \pm 0.30^{\mathrm{Aa}}$ & $8.58 \pm 0.09^{\mathrm{Ca}}$ & $160.00 \pm 0.46^{\mathrm{Ba}}$ \\
\hline Fortuna & $113.08 \pm 0.27^{\mathrm{Ac}}$ & $9.22 \pm 0.17^{\mathrm{Ca}}$ & $45.29 \pm 0.96^{\mathrm{Bb}}$ & $158.98 \pm 0.24^{\mathrm{Ac}}$ & $8.04 \pm 0.39^{\mathrm{Ca}}$ & $43.89 \pm 0.59^{\mathrm{Bb}}$ \\
\hline Margarida & $97.38 \pm 0.52^{\mathrm{Ad}}$ & $6.45 \pm 0.26^{\mathrm{Bc}}$ & $3.54 \pm 0.43^{\mathrm{Cd}}$ & $105.16 \pm 0.10^{\mathrm{Ad}}$ & $7.31 \pm 0.13^{\mathrm{Bb}}$ & $5.85 \pm 0.17^{\mathrm{Cd}}$ \\
\hline
\end{tabular}

Mean of 3 replicates \pm standard deviation on dry basis. Different capital letters on the same line, for each method, correspond to significant difference between different parts for the same varieties $(p<0.05)$ by the Tukey's test. Different small letters in the same column, for each method, correspond to significant difference of the same part for the different varieties $(p<0.05)$ by Tukey's test.

There is a general consensus that antioxidant capacity should be evaluated using different methods in order to analyze different reaction mechanisms (Prior et al., 2005). Therefore, this study used different methods to evaluate the antioxidant capacity by free radical capture mechanisms (DPPH and ABTS) and a method by reduction of $\mathrm{Fe}$ (III) ion (FRAP), besides total phenolic compounds (TPC).

Results obtained using the DPPH, ABTS, and FRAP methods (Table 2) demonstrated similar behaviors. The extract with higher antioxidant capacity among the parts, as well as among the varieties, was the peel of

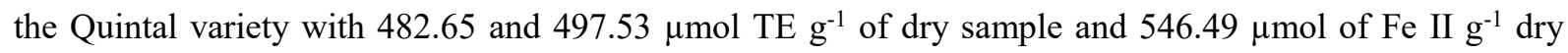
sample, for DPPH, ABTS and FRAP, respectively. There is a significant difference $(p<0.05)$ between the same parts (peel, pulp or seed) of different varieties, as well as between different parts of the same variety. Generally, the antioxidant activity was greater for the peel, followed by seed and pulp, except for ABTS and FRAP results of Margarida variety.

This same tendency was observed in the study conducted by Rodríguez-Carpena et al. (2011), where higher antioxidant capacity was found in the peels and seeds of Hass and Fuerte avocado varieties compared to the pulp

It is possible that the higher antioxidant capacity of peels and seeds may be related to their higher content of antioxidant compounds (phenolic compounds and flavonoids), as shown here and in other recent studies (Daiuto et al., 2014). Wang et al. (2010) found values of $1.3 \mu \mathrm{mol} \mathrm{TE} \mathrm{g}{ }^{-1}, 189.8 \mu \mathrm{mol} \mathrm{TE} \mathrm{g}{ }^{-1}$, and $164.6 \mu \mathrm{mol}$ $\mathrm{TE} \mathrm{g}^{-1}$ for the pulp, peel, and seed of Hass avocado, respectively, using the DPPH method. In addition, the amount and profile of antioxidant phytochemicals changes according to the type, variety, degree of ripeness, 
climate and cultivation (Leong \& Shui, 2002). Recent studies have identified and quantified antioxidant compounds in avocado peel and seeds, especially phenolic compounds, such as catechin and epicatechin in avocado peels (Terasawa et al., 2006), and procyanidins (Wang et al., 2010; Rodríguez-Carpena et al., 2011) in avocado seeds of different cultivars.

It is also worth mentioning that the content of these bioactive compounds found in the pulp along with their residues may vary depending on the cultivar, the edaphoclimatic and cultivation conditions, which include temperature; brightness; fertilization and irrigation; growth, fruit ripening, harvesting and postharvesting, processing and storage (Wang et al., 2012; Vinha et al., 2012).

In PCA analysis of the avocado pulp, the first principal component (PC1) explained $53.41 \%$ of the variance and the second component (PC2) explained 30.57\%, resulting in $83.98 \%$ of the total variance (Figure 1). The variables antioxidant capacity (ABTS and FRAP) and phenolic compound content were well correlated with PC1, and antioxidant capacity against DPPH radical and flavonoid level were better correlated to PC2. The Quintal and Margarida varieties were characterized by higher antioxidant capacity values using the DPPH method and showed the greatest similarity. The Hass variety was characterized by lower antioxidant capacity using ABTS and FRAP, while the Fortuna variety presented lower levels of phenolic compounds and flavonoids. PC1 allowed the differentiation of the Fortuna and Hass varieties; the difference observed between these varieties are related to antioxidant activities according to the ABTS and FRAP methods and to the total phenolic compounds.

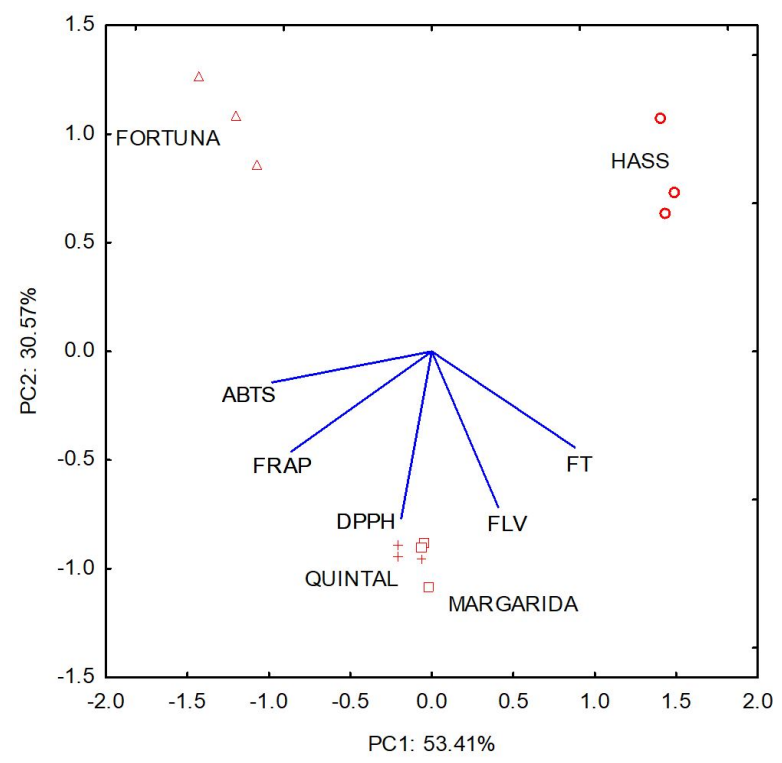

Figure 1. Biplot of scores and loadings from the principal components analysis (PCA) of the antioxidant activity and content of flavonoids and phenolic compounds. PC1 = First principal component; $\mathrm{PC} 2=$ Second principal component

\subsection{Antibacterial activity}

The MIC and MBC values are presented in Table 3. The extracts with the best results were made from the peel of Quintal variety, with $0.625 \mathrm{mg} \mathrm{mL}^{-1}$ for MIC testing and $2.5 \mathrm{mg} \mathrm{mL}^{-1}$ for MBC against the bacteria S. aureus, the microorganism which was the most sensitive to the studied extracts, showing bacteriostatic and bactericidal effects. Meanwhile, extracts made from the pulp, which is the edible part of the fruit, exhibited almost no effects against the tested bacteria. 
Table 3. Minimum Inhibitory Concentration (MIC) and Minimum Bactericidal Concentration (MBC) (mg $\left.\mathrm{mL}^{-1}\right)$ for avocado extracts (from peel, pulp and seed).

\begin{tabular}{|c|c|c|c|c|c|c|c|c|c|}
\hline \multirow{3}{*}{ Varieties } & \multirow{3}{*}{ Parts } & \multicolumn{4}{|c|}{ Gram (-) } & \multicolumn{4}{|c|}{ Gram (+) } \\
\hline & & \multicolumn{2}{|c|}{ E. coli } & \multicolumn{2}{|c|}{ Salmonella } & \multicolumn{2}{|c|}{ B. cereus } & \multicolumn{2}{|c|}{ S. aureus } \\
\hline & & MIC & MBC & MIC & MBC & MIC & MBC & MIC & MBC \\
\hline \multirow{3}{*}{ Hass } & Peel & 10 & - & 10 & - & 10 & - & 1.25 & 10 \\
\hline & Pulp & $>20$ & NP & $>20$ & NP & $>20$ & NP & $>20$ & NP \\
\hline & Seed & 20 & - & 20 & - & 20 & - & 5 & 20 \\
\hline \multirow{3}{*}{ Quintal } & Peel & 5 & - & 5 & - & 5 & - & 0.625 & 2.5 \\
\hline & Pulp & $>20$ & NP & $>20$ & NP & $>20$ & NP & 20 & - \\
\hline & Seed & 10 & - & 10 & - & 10 & - & 2.5 & 20 \\
\hline \multirow{3}{*}{ Fortuna } & Peel & 5 & - & 10 & - & 10 & - & 1.25 & 10 \\
\hline & Pulp & $>20$ & NP & $>20$ & NP & $>20$ & NP & $>20$ & NP \\
\hline & Seed & 10 & - & 10 & - & 10 & - & 1.25 & 10 \\
\hline \multirow{3}{*}{ Margarida } & Peel & 20 & - & 20 & - & 20 & - & 2.5 & 10 \\
\hline & Pulp & $>20$ & NP & $>20$ & NP & $>20$ & NP & $>20$ & NP \\
\hline & Seed & 20 & - & 20 & - & 20 & - & 2.5 & 20 \\
\hline
\end{tabular}

$(-)=$ Not determined in the tested concentration range. $\mathrm{NP}=$ Not performed.

According to Chakraborty \& Mitra (2008), most studies on antibacterial as well as antioxidant activities attribute antimicrobial activity to the phenolic content of extracts, thereby establishing a direct relationship between the two activities. This was verified in this present study, in which the Quintal peel extract (which had the highest levels of phenolic compounds and flavonoids) demonstrated the best results for antioxidant and antibacterial activities, followed by the Hass variety, which also showed low concentrations in the tests against the selected bacteria.

Antibacterial activity was higher against gram-positive bacteria, mainly $S$. aureus, than in the gram-negative bacteria. Some authors have already reported this finding (Gonçalves et al., 2011; Paz et al., 2015; Rodríguez-Carpena et al., 2011), which may be attributed to the membrane structure. Gram-negative bacteria are composed by a structure with several layers and have an outer membrane composed by lipopolysaccharides with a higher fat content in the cell wall that allows less interaction with the extracts (Gonçalves et al., 2011). Furthermore, since most of the extracts are hydrophilic in nature, because of the types of solvents with different polarities which are employed in the extraction, their interaction with the gram-negative bacterial cell wall is probably hampered (Paz et al., 2015). This is not the case with gram-positive bacteria, such as $S$. aureus, because they have no outer membrane and are more hydrophilic, facilitating the interaction of the extract with the bacterial cell wall.

In the study conducted by Rodríguez-Carpena et al. (2011), the disk diffusion test found gram-positive bacteria to be more sensitive than gram-negative bacteria. However, the best results in that study were obtained from the fruit pulp extracts, which showed a larger zone of inhibition than extracts from the other parts. These findings differed from the present study, in which the pulp extracts showed no activity against the bacteria used in MIC testing. This may have occurred because the concentrations used in the tests were different, with higher concentrations in the study above mentioned.

Results for the studied avocado extracts are promising, especially the peel of Quintal variety, which yielded the lowest concentration in the MIC and MBC tests and could be used in preventing contamination from food handling. 


\subsection{Toxicity testing}

Preliminary toxicity tests were performed using the peel of Quintal variety, since it presented the best results for antioxidant and antibacterial activities and has great potential for food use.

With regard to toxicity against $A$. salina, $\mathrm{LC}_{50}$ was $204.95 \mathrm{mg} \mathrm{mL}^{-1}$ of the extract, calculated using linear regression (Figure 2). According to Meyer et al. (1982), an extract is considered toxic if the $\mathrm{LC}_{50}$ value is less than $1000 \mu \mathrm{g} \mathrm{mL}^{-1}$ and non-toxic if the $\mathrm{LC}_{50}$ value exceeds this number for testing with $A$. salina. Therefore, since the $\mathrm{LC}_{50}$ level for this extract was $204.95 \mathrm{mg} \mathrm{mL}^{-1}$, it was shown to have no toxic effects against $A$. salina.

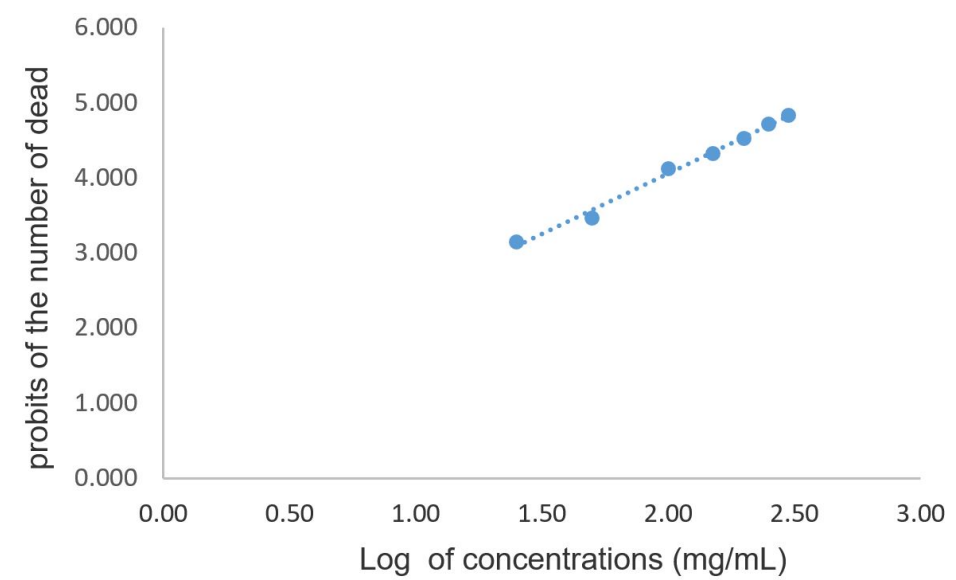

Figure 2. Linear regression for extract concentration from the peel of Quintal variety. $Y=1.6063 x+0.8468 . R^{2}=$ 0.9917.

This result initially shows the concentration that can kill $50 \%$ of the A. salina individuals tested. In agreement with these results, we found that there was no mortality in the A. salina larvae in the negative control group which received only saline solution, and the nauplii remained active. For the positive control group there was mortality in all the larvae, indicating high toxicity for the potassium dichromate.

According to Nofiani et al. (2011), hemolytic action should be considered elevated when hemolysis exceeds $40 \%$, and low when this value is less than $10 \%$. Intense hemolysis was seen for samples (Table 4 ) at higher concentrations, with $61.07 \%$ for the $300 \mathrm{mg} \mathrm{mL}^{-1}$ concentration. However, in concentrations of up to $150 \mathrm{mg} \mathrm{mL}^{-1}$ the hemolysis values were considered low to moderate, and the $\mathrm{LC}_{50}$, concentration causing $50 \%$ hemolysis was $229.22 \mathrm{mg} \mathrm{mL}^{-1}$.

Table 4. Cytotoxicity test (\%) for the peel crude extract of Quintal variety for the hemolysis test.

\begin{tabular}{cc} 
Concentration $\left(\mathbf{m g ~ m L}^{-1}\right)$ & \% hemolysis \\
\hline Negative control & $0 \pm 0.0$ \\
Positive control & $100 \pm 0.0$ \\
25 & $4.50 \pm 0.02$ \\
50 & $13.19 \pm 0.08$ \\
100 & $26.11 \pm 0.05$ \\
150 & $37.76 \pm 0.01$ \\
200 & $44.33 \pm 0.02$ \\
250 & $55.14 \pm 0.02$ \\
300 & $61.07 \pm 0.02$ \\
\hline
\end{tabular}

Mean of 3 replicates \pm standard deviation. 
The literature contains few studies investigating the toxicological and genotoxic characteristics of avocado byproducts such as peel and seed. The toxicity tests in this study showed that the peel extract of Quintal variety of avocado had no toxicological effects in testing against $A$. salina, and the hemolytic activity resulted in a $\mathrm{LC}_{50}$ value similar to that of the brine shrimp test. The absence of toxicity we observed encourages additional studies for the use of these extracts as food additives, since they are strong natural antioxidants and antibacterials and show potential for use in this type of product.

\section{Conclusions}

The highest antioxidant and microbiological activity was observed in the ethanolic extracts of peels, followed by the seeds of Quintal, Hass, Fortuna, and Margarida varieties of avocado. The extract from Quintal peel performed better in all tests, and may be used as natural antioxidant or to assist in the prevention of food contamination through handling, especially against the bacteria $S$. aureus, which is found on human skin. Toxicity testing for this extract also indicated that it did not demonstrate toxicological effects in testing with $A$. salina or hemolytic activity, and consequently this component appears to be a promising alternative for food applications to prevent decay and consequently increase shelf life.

\section{References}

Benzie, I. F., \& Strain, J. J. (1996). The ferric reducing ability of plasma (FRAP) as a measure of "antioxidant power": the FRAP assay. Analytical Biochemistry, 239(1), 70-76. PMid:8660627. http://dx.doi.org/10.1006/abio.1996.0292

Bondet, V., Brand-Williams, W., \& Berset, C. (1997). Kinetics and mechanisms of antioxidant activity using the DPPH free radical method. Lebensmittel-Wissenschaft + Technologie, 30(6), 609-615. http://dx.doi.org/10.1006/fstl.1997.0240

Boroski, M., Visentainer, J. V., Cottica, S. M., \& Morais, D. R. (2015). Antioxidantes: princípios e métodos analíticos (1. ed.) Curitiba: Appris. 141 p.

Chakraborty, M., \& Mitra, A. (2008). The antioxidant and antimicrobial properties of the methanolic extract from Cocos nucifera mesocarp. Food Chemistry, 107(3), 994-999. http://dx.doi.org/10.1016/j.foodchem.2007.08.083

Clinical and Laboratory Standards Institute - CLSI. (2012). Methods for dilution antimicrobial susceptibility tests $f$ or bacteria that grow aerobically: Approved standard (9th ed.). Wayne: CLSI. CLSI document M07-A9.

Daiuto, E. R., Tremocoldi, M. A., Alencar, S. M., Vieites, R. L., \& Minarelli, P. H. (2014). Chemical composition and antioxidant activity of pulp and residues of 'Hass' avocado. Brazilian Journal of Fruticulture, 36(2), 417-424. Retrieved in 2018, February 21, from http://www.scielo.br/scielo.php?script=sci_arttext\&pid=S0100-29452014000200018

Dixon, R. A., \& Paiva, N. I. (1995). Stress-induced phenylpropanoid metabolism. The Plant Cell, 7(7), 1085-1097.

PMid:12242399. http://dx.doi.org/10.1105/tpc.7.7.1085

Food and Agricultural Organization - FAO. (2017). FAOSTAT database. Rome: FAO.

Gonçalves, G. M. S., Santos, N. P., \& Srebernich, S. M. (2011). Antioxidant and antimicrobial activities of propolis and açai (Euterpe oleracea Mart) extracts. Journal of Basic and Applied Pharmaceutical Sciences, 32(3), 349-356. Retrieved in 2018, February 21, from http://serv-bib.fcfar.unesp.br/seer/index.php/Cien_Farm/article/viewArticle/1728

Ignat, I., Volf, I., \& Popa, V. (2011). A critical review of Methods for characterization of polyphenolic compunds in fruits and vegetables. Food Chemistry, 126(4), 1821-1835. PMid:25213963. http://dx.doi.org/10.1016/j.foodchem.2010.12.026

Informa Economics IEG. (2017). Agrianual 2017: Brazilian agriculture yearbook (22. ed.). São Paulo: FNP Consulting \& Agroinformatives. $450 \mathrm{p}$.

Kate, I. E., \& Lucky, O. O. (2009). Biochemical evaluation of the tradomedicinal uses of the seeds of Persea Americana Mill. (Family: Lauraceae). World Journal of Medical Sciences, 4(2), 143-146. Retrieved in 2018, February 21, from https://www.idosi.org/wjms/4(2)09/14.pdf

Leong, L. P., \& Shui, G. (2002). An investigation of antioxidant capacity of fruit in Singapore markets. Food Chemistry, 76(1), 69-75. http://dx.doi.org/10.1016/S0308-8146(01)00251-5

Matsusaka, Y., \& Kawabata, J. (2010). Evaluation of antioxidant capacity of non-edible parts of some selected tropical fruits. Food Science and Technology Research, 16(5), 467-472. http://dx.doi.org/10.3136/fstr.16.467

Meyer, B. N., Ferrigni, N. R., Putnam, J. E., Jacobsen, L. B., Nichols, D. E., \& McLaughlin, J. L. (1982). Brine shrimp: A convenient general bioassay for active plant constituents. Planta Medica, 45(5), 31-34. http://dx.doi.org/10.1055/s-2007-971236

Nofiani, R., Kurniadi, R., \& Ardiningsih, P. (2011). Antimicrobial, antioxidant, hemolytic activities and toxicity of ethyl acetate extract from an unidentified coral associated fungus, Aspergillus brevipes RK06. Indonesian Journal of Cancer Chemoprevention, 2(2), 211-215. http://dx.doi.org/10.14499/indonesianjcanchemoprev2iss2pp212-216 
Paz, M., Gúllon, P., Barroso, M. F., Carvalho, A. P., Domingues, V. F., Gomes, A. M., Becker, H., Longhinotti, E., \& DelerueMatos, C. (2015). Brazilian fruit pulps as functional foods and additives: Evaluation of bioactive compounds. Food Chemistry, 172, 462-468. PMid:25442579. http://dx.doi.org/10.1016/j.foodchem.2014.09.102

Prior, R. L., Wu, X., \& Schaich, K. (2005). Standardized methods for the determination of antioxidant capacity and phenolics in foods and dietary supplements. Journal of Agricultural and Food Chemistry, 53(10), 4290-4302. PMid:15884874. http://dx.doi.org/10.1021/jf0502698

Re, R., Pellegrini, N., Proteggente, A., Pannala, A., Yang, M., \& Rice-Evans, C. (1999). Antioxidant activity applying and improved ABTS radical cátion decolorization assay. Free Radical Biology \& Medicine, 26(9-10), 1231-1237. PMid:10381194. http://dx.doi.org/10.1016/S0891-5849(98)00315-3

Ribeiro, A. B., Bonafé, E. G., Silva, B. S., Montanher, P. F., Santos, O., Boeing, J. S., \& Visentainer, J. V. (2013). Antioxidant capacity, total phenolics content, fatty acids and correlation by principal component analysis of exotic and native fruits from Brazil. Journal of the Brazilian Chemical Society, 24(5), 797-804. http://dx.doi.org/10.5935/0103-5053.20130105

Rodríguez-Carpena, J., Morcuende, D., Andrade, M. J., Kylli, P., \& Estévez, M. (2011). Avocado (Persea americana Mill) phenolics, in vitro antioxidant and antimicrobial activies, and inhibition of lipid and protein oxidation in porcine patties. Journal of Agricultural and Food Chemistry, 59(10), 5625-5635. PMid:21480593. http://dx.doi.org/10.1021/jf1048832

Scherer, R., \& Godoy, H. T. (2009). Antioxidant activity index (AAI) by the 2,2-diphenyl-1-picrylhydrazyl method. Food Chemistry, 112(3), 654-658. http://dx.doi.org/10.1016/j.foodchem.2008.06.026

Singleton, V. L., \& Rossi Jr, J. A. (1965). Colorimetry of total phenolics with phosphomolybdic-phosphotungstic acid reagents. American Journal of Enology and Viticulture, 16(1), 144-158.

Soares, L. A. L., González Ortega, G., Bassani, V. L., \& Petrovick, P. R. (1998). Desenvolvimento tecnológico de solução extrativa aquosa de Phyllanthus niruri L. (quebra-pedra) empregando planejamento fatorial. Caderno de Farmácia, 14(1), 21-26. Retrieved in 2018, February 21, from http://hdl.handle.net/10183/19302

Terasawa, N., Sakakibara, M., \& Murata, M. (2006). Antioxidative activity of avocado epicarp hot water extract. Food Science and Technology Research, 12(1), 55-58. http://dx.doi.org/10.3136/fstr.12.55

Tiuman, T. S., Ueda-Nakamura, T., Dias Filho, B. P., Cortez, D. A. G., \& Nakamura, C. V. (2005). Studies on the effectiveness of Tanacetum parthenium against Leishmania amazonensis. Acta Protozoologica, 44(1), 245-251.

Vinha, A. F., Soares, M. O., Herdeiro, T., \& Machado, M. (2012). Chemical composition and antioxidant activity in portuguese diospyrus kaki fruit by geographical origins. The Journal of Agricultural Science, 4(2), 281-289.

Wang, M., Zheng, Y., Khuong, T., \& Lovatt, C. J. (2012). Effect of harvest date on the nutritional quality and antioxidant capacity in 'Hass' avocado during storage. Food Chemistry, 135(2), 694-698. PMid:22868147.

http://dx.doi.org/10.1016/j.foodchem.2012.05.022

Wang, W., Bostic, T. R., \& Gu, L. (2010). Antioxidant capacities, procyanidins and pigments in avocados of different strains and cultivars. Food Chemistry, 122(4), 1193-1198. http://dx.doi.org/10.1016/j.foodchem.2010.03.114

Woisky, R. G., \& Salatino, A. (1998). Analysis of propolis: some parameters and procedures for chemical quality control. Journal of Apicultural Research, 37(2), 99-105. http://dx.doi.org/10.1080/00218839.1998.11100961 